\title{
Analysis of Socialization Situations via Sport-based Physical Activity among Students at a School of Physical Education and Sports
}

\author{
Mehmet Yildirim* \\ University of Yozgat Bozok, TURKEY
}

\author{
Cagdas Caz \\ University of Yozgat Bozok, TURKEY
}

Received: August 13, 2018 - Revised: October 23, $2018 \cdot$ Accepted: October 24, 2018

\begin{abstract}
This study aims to determine socialization situations via sport-based physical activity among students at a school of physical education and sports in terms of their demographic features. The population of the study comprises of 480 students studying in different departments at School of Physical Education and Sports at University of Yozgat Bozok during 2017-2018 academic year. The sample of the study comprises of 300 students selected based on convenience sampling method and studying at different departments of School of Physical Education and Sports at University of Yozgat Bozok during 2017-2018 academic year. Personal information form and socialization via sport-based physical activity developed by Yildirim was used as a data collection tool in this search. Frequency analysis, arithmetic mean, $t$ test, Anova test and post-hoc tests were used in the data analysis. The findings of the study demonstrate that significant differences were found between socialization sub-dimensions and sport-based physical activity in terms of gender, monthly expenses, academic department and sports branch varibles $(\mathrm{p}<.05)$.
\end{abstract}

Keywords: Physical activity, socializing, university, student.

To cite this article: Yildirim, M., \& Caz, C. (2018). Analysis of socialization situations via sport-based physical activity among students at a school of physical education and sports. European Journal of Educational Research, 7(4), 999-1010. doi: 10.12973/eujer.7.4.999

\section{Introduction}

Human beings express themselves through their behaviors in a society, which makes them different from others in a society and also turn them into a member of that society. All individuals are born into a group of people and acquire their social traits in this group. Lifestyle, group awareness and values in a society are transmitted to individual through their groups. An individual who adopts these awareness and values gradually becomes a solid member of that society (Yetim, 2000). While physical structure and biological factors lay the grounds for material development, intelligence and instincts contribute to spirituality. In addition, it is acknowledged that social and family values greatly shape an individual's spirituality (Guney, 2000), which is of vital importance for their socialization.

Socialization is defined as the development and internalization of various skills, knowledge, values, tendencies and sense of self which are required to fulfill existing or expected roles in a society (Kenyon and Person, 1974). It can be considered as a mechanism which enables an individual to integrate into the culture and comply with social norms (Donmezer, 1984). It also transmits cultural values from one generation to the other and thus helps an individual to adapt to various norms in an organized social life (Tolan, 1993). It entails an individual's behaviors against others and is a life-long developing phenomenon (Mengutay, 2006).

Socialization aims to teach an individual how to behave and conform to expectations in a cultural environment as well as preparing them for a harmonious life with other members of the society, thus making them a part of that society. They learn to become integrated into social institutions such as family, school, social circle and professional organizations (Yetim, 2000). Most of human behaviors are learned behaviors. People learn these behaviors within a socialization process in a given society. This process involves learning a native language from the moment when an individual is born and culture as well as transmitting it to upcoming generations (Acik Ogretim Fakultesi, 2003).

Socialization represents an individual's integration into society and expectations of that social culture. It is only possible for an individual tries to live a community life with other people when they welcome social traditions, customs, clothing, sleeping, eating, entertainment and working habits, acknowledge some basic social techniques, obey by some social rules and norms, and, finally, fulfill expected social roles (Donmezer, 1994).

\footnotetext{
* Corresponding author:

Mehmet Yildirim, University of Yozgat Bozok, School of Physical Education and Sports, Yozgat, Turkey,

Email: mehmet2682@hotmail.com
} 
Socialization process as a social phenomenon is the entire process that provides an individual with social membership following their birth (Erkal et al., 1998). It is a lifelong learning process, and has a great role in the transmission of culture from one generation to the other (Kagitcibasi, 1999). As a learning process, it tranmsits socio-cultural values in a given society in order to transform an individual into an acceptable member who conforms to various expectations of that society (Sayin, 1999). According to Tolan (1987), thanks to interactions with other people, socialization transmits social value judgments such as good-bad and right-wrong as well as all other socially acceptable values, norms, attitudes, behaviors and skills.

Socialization is gained in numerous social circles with a lot of people in a number of different ways. Parents, friends, teachers, teammates, coaches, colleagues, partners and spouses contribute to this process from different perspectives (Yetim, 2006). The process contains countless rules about how to properly lead a life and behave in a society, circle of friends and family. As a result, an individual interacts and communicate with other people in this process to prepare themselves for social environment, thus having a certain character, conforming to social environment and adapting to their respective society (Cosgun, 2012).

Pscyho-social learning must function properly as a result of social interaction for a healthy socialization process. In this way, it is possible for an individual to easily adapt to social life. Sport activities offer a great atmosphere for this process (Ozdinc, 2005).

Any physical and sport activity is a social experience and involves emotions. An individual actively being involved in sport activities finds an opportunity to expressive their feelings through games and movements. It helps release emotions such as anger, shyness, jealousy etc. (Yetim, 2000). It enables to suppress aggressive behaviors and control oneself by spending this suppressed energy (Guven, 1998). It is important to take part in games and sport activities to relieve suppressed energy. In addition to physical development, participation in sports activities also contributes to one's personal development. Personality can be defined as an individual's awareness about their state of mind, goals and status/reputation in their social environment. A person can reach such awareness by comparing themselves with other people. A child can only understand his/her weaknesses and strengths when s/he starts to play with other children, and compares his/her skills with them (Yetim, 2000).

An individual socializes in their early life and gains a habit of doing sports during childhood and adolescence, which requires dealing with sports and socialization within the framework of same periods. Various games and sports reflect social realities because games and sports mostly involve necessary processes for socialization in a society. Various stages of socialization such as role playing, status, social stratification, approval, leadership, discipline, competition and collaboration can be effectively experienced in games and sports (Erkal et al., 1998). According to Parks (1993), sport brings people together and give them a social and individual identity and a sense of membership within the group. Popularity of sports and its nature that does not prioritize social class, gender, race and age gives a better opportunity to fulfill social roles. Additionally, sports go beyond social tension and conflict by making communication easier among people and societies. It has the strength to make an individual a member of a family, neighbourhood team, city or nation. It helps people overcome prejudices and oppression, and turns them into more respectful and realist individuals (Yildiran \& Yetim, 1996). It develops skills such as empathy, responsibility, coordination and collaboration. It plants the sense of belonging to a social group and society, and ensures the continuity of individual and social relationships (Erkal, 1986).

Despite the critical role of sports in socialization, it is still possible to encounter some negative results as a result of differing expectations of individuals who join sport activities. In addition, great economic incomes in the field of sports encourage people to professionally perform sport activities. However, failures in a sport branch are likely to trigger losing interest in that sport and thus cause an individual to avoid social relationships with other people. Therefore, from early childhood, it bears utmost importance to urge children to participate and become involved in sport activities based on their talents and interest. Excessive sports activities may lead to negative results because it may disrupt an individual's daily life. For instance, productive sport programs which will guide students towards relaxing and academic-related activities rather than those which will prevent them from concentrating on their classes and home works should be developed. It is underlined in various studies that numerous problems may arise in a socialization process involving sports when the desire to compete and win is excessively emphasized, coaches, family and friends express far-reaching expectations from students, individuals' skills are negatively evaluated and individuals do not find enough time to join sport activities (Orlick, 1974; Pooley, 1981). In order to eliminate these problems, governments should invest in sport projects with a view to raising healthy, strong, social and well-informed children and adolescents.

Because sport directly addresses human factor, it can be effectively used as a tool to create a healthy and productive society, bring up a constructive, creative and healthy youth that will build a positive future and struggle against social disintegration and alienation. In this respect, it cannot be denied that sport fulfills an active and indispensable role as a social phenomenon (Yildiran and Yetim, 1996).

This study aims to determine socialization situations via sport-based physical activity among students at a school of physical education and sports in terms of their demographic features. To this aim, the following research questions will be answered: 
- What are socialization situations via sport-based physical activity among students at School of Physical Education and Sports?

- Is there a statistically significant difference between sport-based physical activity and socialization subdimensions in terms of gender?

- Is there a statistically significant difference between sport-based physical activity and socialization subdimensions in terms of age?

- Is there a statistically significant difference between sport-based physical activity and socialization subdimensions in terms of academic department?

- Is there a statistically significant difference between sport-based physical activity and socialization subdimensions in terms of monthly expenses?

- Is there a statistically significant difference between sport-based physical activity and socialization subdimensions in terms of residence type?

- Is there a statistically significant difference between sport-based physical activity and socialization subdimensions in terms of sport branch?

\section{Methodology}

\section{Study Group}

This study uses descriptive research model in order to analyze socialization situations via sport-based physical activity among students at School of Physical Education and Sports. In addition, relational research model was used to analyze the relationship between students' mean socialization sub-dimension scores and demographic features. The population of the study comprises of 480 students studying at different departments of School of Physical Education and Sports at University of Yozgat Bozok during 2017-2018 academic year. The sample of the study comprises of 300 students selected based on convenience sampling method and studying at different departments of School of Physical Education and Sports at University of Yozgat Bozok during 2017-2018 academic year.

\section{Data Collection Tools}

Questionnaire, which is a primary source research, was used as a data collection tool to conduct the present study due to its cost-effectiveness, feasibility and suitability for collecting information from dispersed and large masses within a short time. The questionnaire form used in the present study is divided into two parts. In the first part, participants' personal and social features were determined using limited items (gender, age, montly expenses, residence type, academic department and sport branch). In the second part, a 5-point Likert type scale ("1: Disagree", "2: Slightly Agree”, “3: Moderately Agree Katiliyorum”, “4: Strongly Agree”, “5: Totally Agree) was used.

Socialization via sport-based physical activity scale: In the present study, 5-point Likert type sport and socialization scale consisting of 35 questions and developed by Sahan (2007) was used to identify participants' socialization situations via sport-based physical activity. Likert type scale is one of the most widely used scaling methods due to its reliability, construct and ease of use (MEB, 2012; 8). Sport and socialization scale is based on a Likert-scale as "1: Strongly Disagree”, “2: Disagree”, “3: Don't Know”, “4: Agree”, “5: Strongly Agree”. The scale was created using existing scales such as Hacettepe personality inventory, socio-trophy autonomy scale, social comparison scale, social recognition questionnaire, self-definition inventory and personal information form. In addition, Sahan (2007) performed a reliability test for the questionnaire. Cronbach $\alpha$ reliability coefficient was used for the measurement of internal consistency for 35 questions, which yielded a Cronbach $\alpha$ value of 0.84 .

Table 1. Numerical-verbal values of options in judgement rating scales (http 1)

\begin{tabular}{llllc}
\hline None & Slightly & Moderately & Strongly & Totally \\
\hline \multicolumn{1}{c}{1} & \multicolumn{1}{c}{3} & \multicolumn{1}{c}{4} & 5 \\
\hline Strongly Disagree & Slightly Agree & Moderately Agree & Strongly Agree & Totally Agree \\
$\% 0$ & $\% 25$ & $\% 50$ & $\% 75$ & $\% 100$ \\
Totally Disagree & Strongly Disagree & Moderately Disagree & Slightly Disagree & Agree \\
$\% 100$ & $\% 75$ & $\% 50$ & $\% 25$ & $\% 0$ \\
\hline
\end{tabular}

On the other hand, Likert rating in the scale was rearranged by Yildirim (2015) as "1: Strongly Disagree", "2: Slightly Agree”, "3: Moderately Agree”, "4: Strongly Agree”, "5: Totally Agree”) in accordance with numerical and verbal values of the options. Cronbach $\alpha$ reliability coefficient was used for the measurement of internal consistency of the answers to 35 questions, which yielded a Cronbach $\alpha$ value of 0.86 . According to Ozdamar (199), Cronbach $\alpha$ value of 0.60 is sufficient for a reliable scale, demonstrating that this scale is a reliable one. 
An exploratory and confirmatory factor analysis was applied to the scale by Yildirim (2015). The analysis was performed on 1026 students studying at different departments of Eskisehir Osmangazi University. As a result of the factor analysis, items with a low loading factor value and cyclical structure were omitted from the scale. Sport and socialization scale was represented by 4 dimensions and 15 items which define these dimensions, namely as Personal and Social Integration, Leadership, Sense of Belonging and Confidence. The scale was named as socialization via sportbased physical activity scale. Factor loading values of the scale vary between $0.52 / 0.83$, while Cronbach $\alpha$ values of the dimensions vary between $0.48 / 0.86$. The total variance of the scale was explained as $61.550 \%$, while total reliability was calculated as 0.84 .

A confirmatory factor analysis was applied to 4 sub-dimensions of socialization via sport-based physical activity scale by Yildirim (2015). The analysis was performed on 1026 students studying at different departments of Eskisehir Osmangazi University. The analysis results related to goodness of fit indexes of the scale are given in Table 2.

Table 2. Goodness of fit index for sport-focuses physical activity socialization scale

\begin{tabular}{lc}
\hline Goodness of fit index & Values \\
\hline $\mathbf{X}^{2}$ value & 3.35 \\
sd value & 2 \\
$\mathbf{X}^{2} / \mathbf{s d}$ & 1.67 \\
RMSEA (Root Mean Square Error of Approxomination) value & 0.03 \\
NFI(Normed Fit Index) value & 0.99 \\
NNFI (Non-Normed Fit Index) value & 0.99 \\
CFI (Comparative Fit Index) value & 1.00 \\
RMR (Root Mean Square Residual) & 0.01 \\
GFI (Goodness of Fit Index) value & 1.00 \\
AGFI (Adjusted Goodness of Fit Index) value & 0.98 \\
\hline
\end{tabular}

Because corrected $\mathrm{X}^{2}$ value $\left(\mathrm{X}^{2} / \mathrm{sd}=3.35 / 2\right)$ was obtained as 1.67 , the scale was considered as statistically significant (Yildirim, 2015). RMSEA, NFI, NNFI, CFI, RMR, GFI and AGFI goodness of fit indexes were also analyzed following CFA. RMSEA value was calculated as 0.03 . A RMSEA value lower than or equal to 0.05 means a good goodness of fit, a value between 0.05 and 0.08 means a sufficient goodness of fit, and a value between 0.08 and 0.10 means a mediocre goodness of fit. Finally, a value higher than 0.10 means that the model is unacceptable (Schermelleh et al., 2003; Cokluk et al., 2010;269; Meydan and Sesen, 2011;34). RMR value of the scale was calculated as 0.01. RMR value lower than or equal to 0.05 means an excellent goodness of fit, a value between 0.05 and 0.08 means a good goodness of fit, and a value between 0.08 and 0.10 means a mediocre goodness of fit. In addition, NFI, NNFI, CFI, GFI and AGFI values of the scale were calculated as $0.99,0.99,1.00,1.00$ and 0.98 , respectively, demonstrating that the scale has an excellent goodness of fit for these values (Cokluk et al., 2010; 271-272, Kaya, 2011; 65).

CFA analysis applied to 4 sub-dimensions of the socialization via sport-based physical activity scale indicates that goodness of fit indexes of the scale comply with the values reported in the literature and thus display an excellent goodness of fit.

\section{Procedure}

The data were collected from students studying at different departments of School of Physical Education and Sports at University of Yozgat Bozok during 2017-2018 academic year. The questionnaire was conducted by the researcher. Before the questionnaire was conducted, participants were informed about voluntary participation in the study and optional withdrawal from the study without any sanctions at any time, and they were ensured that their answers would remain anonymous and be only used in parallel with the aim of this study. In addition, all participants were asked to sign a written consent form prior to the survey.

\section{Data Analysis}

In order to analyze the data obtained from the present study, frequency analysis was used to describe students' demographic features. In addition, arithmetic means and standard deviation analysis were used to identify the most important sub-dimension of the socialization via sport-based physical activity scale. t-test and ANOVA was used to determine differences between sport-based physical activity and socialization situations in terms of demographic variables. Finally, multiple comparison (Post-HocTukey HSD and Tamhane T2) tests were used for variance homogeneity. 


\section{Findings}

The findings related to the participants' demographic features are given in Table 3.

Table 3. Participants' demographic features

\begin{tabular}{|c|c|c|c|}
\hline & & $\mathbf{N}$ & $\%$ \\
\hline \multirow[t]{2}{*}{ Gender } & Female & 129 & 43.0 \\
\hline & Male & 171 & 57.0 \\
\hline \multirow[t]{10}{*}{ Age } & 18.00 & 52 & 17.3 \\
\hline & 19.00 & 90 & 30.0 \\
\hline & 20.00 & 73 & 24.3 \\
\hline & 21.00 & 44 & 14.7 \\
\hline & 22.00 & 19 & 6.3 \\
\hline & 23.00 & 12 & 4.0 \\
\hline & 24.00 & 3 & 1.0 \\
\hline & 25.00 & 5 & 1.7 \\
\hline & 27.00 & 1 & .3 \\
\hline & 30.00 & 1 & .3 \\
\hline \multirow[t]{5}{*}{ Monthly Expenses } & $500 \mathrm{TL}$ and less & 125 & 41.7 \\
\hline & $501 \mathrm{TL}-750 \mathrm{TL}$ & 69 & 23.0 \\
\hline & 751 TL-1000TL & 48 & 16.0 \\
\hline & $1001 \mathrm{TL}-1250 \mathrm{TL}$ & 38 & 12.7 \\
\hline & 1251 TL and more & 20 & 6.7 \\
\hline \multirow[t]{4}{*}{ Residence Type } & Alone & 9 & 3.0 \\
\hline & With my family & 18 & 6.0 \\
\hline & With a flat mate & 109 & 36.3 \\
\hline & At dormitory & 164 & 54.7 \\
\hline \multirow[t]{3}{*}{ Academic Department } & Physical Education and Sports Teaching & 119 & 39.7 \\
\hline & Coaching Education & 128 & 42.7 \\
\hline & Sports Management & 53 & 17.7 \\
\hline \multirow[t]{3}{*}{ Sport Branch } & Individual Sports & 135 & 45.0 \\
\hline & Team Sports & 135 & 45.0 \\
\hline & No branch & 30 & 10.0 \\
\hline
\end{tabular}

Table 3 demonstrates that there are 129 female (43\%) and 171 male (57\%) participants in the present study. 52 students $(17.3 \%)$ are 18,90 students $(30 \%)$ are 19,73 students $(24.3 \%)$ are 20,44 students (14.\%7) are 21,19 students $(6.3 \%)$ are 22,12 students $(4.0 \%)$ are 23,3 students are $(1.0 \%) 24,5$ students are $(1.7 \%) 25,1$ student $(0.3 \%)$ is 27 and 1 student $(0.3 \%)$ is 30 years old. When it comes to students' monthly expenses, 125 students (41.7\%) spend 500 TL and less, 69 students (23.0\%) spend between 501 TL and 750 TL, 48 students(16.0\%) spend between $751 \mathrm{TL}$ and $1000 \mathrm{TL}, 38$ students (12.7\%) spend between $1001 \mathrm{TL}$ and $1250 \mathrm{TL}, 20$ students (6.7\%) spend 1251 TL and more. 9 students (3.0\%) live alone, 18 students (6.0\%) lives with their family, 109 students (36.3\%) live with a flat mate, and 164 students (54.7\%) lives at a dormitory. In terms of academic departments, 119 students (39.7\%) study physical education and sports teaching, 128 students (42.7\%) study coaching education, and 53 students (17.7\%) study sports management. While 135 students (45.0\%) are involved in individual sports, 135 students (45.0\%) are involved in a team sport. 30 students $(10.0 \%)$ do not have a sport branch.

Findings related to the sub-dimensions of socialization via sport-based physical activity are given in Table 4 .

Tablo 4. Findings related to the sub-dimensions of socialization via sport-based physical activity

\begin{tabular}{lccccc}
\hline & & & & \multicolumn{2}{c}{ Arithmetic } \\
& $\mathrm{N}$ & Minimum & Maximum & Mean & Standard Deviation \\
\hline Personal and Social Integration & 300 & 1.00 & 5.00 & 4.41 & .721 \\
\hline Leadership & 300 & 1.00 & 5.00 & 3.73 & .844 \\
\hline Sense of Belonging & 300 & 1.00 & 5.00 & 3.88 & .890 \\
\hline Confidence & 300 & 1.00 & 5.00 & 3.80 & 1.013 \\
\hline
\end{tabular}

Table 4 demonstrates that the highest arithmetic mean in the scale was obtained in the sub-dimension of personal and social integration (?=4.41).

t-test findings related to mean sub-dimension scores in terms of gender are given in Table 5. 
Table 5. $t$-test findings related to mean sub-dimension scores in terms of gender

\begin{tabular}{|c|c|c|c|c|c|c|}
\hline & Gender & $\mathbf{N}$ & Mean & Sd & $\mathbf{T}$ & $\mathbf{p}$ \\
\hline \multirow{2}{*}{ Personal and Social Integration } & Female & 129 & 4.42 & .688 & \multirow{2}{*}{.275} & \multirow{2}{*}{.784} \\
\hline & Male & 171 & 4.40 & .747 & & \\
\hline \multirow{2}{*}{ Leadership } & Female & 129 & 3.78 & .813 & \multirow{2}{*}{.938} & \multirow{2}{*}{.349} \\
\hline & Male & 171 & 3.69 & .866 & & \\
\hline \multirow{2}{*}{ Sense of Belonging } & Female & 129 & 3.99 & .805 & \multirow{2}{*}{1.873} & \multirow{2}{*}{.062} \\
\hline & Male & 171 & 3.80 & .943 & & \\
\hline \multirow{2}{*}{ Confidence } & Female & 129 & 3.96 & .937 & \multirow{2}{*}{2.460} & \multirow{2}{*}{.014} \\
\hline & Male & 171 & 3.68 & 1.054 & & \\
\hline
\end{tabular}

Table 5 indicates a statistically significant difference in the sub-dimension of confidence in terms of gender $(\mathrm{t}=2.460$; $\mathrm{p}=.014$ ). ANOVA test findings related to mean sub-dimension scores in terms of age are given in Table 6.

Table 6. ANOVA test findings related to mean sub-dimension scores in terms of age

\begin{tabular}{|c|c|c|c|c|}
\hline & & df & $\mathbf{F}$ & $\mathbf{P}$ \\
\hline & Between Groups & 9 & & \\
\hline \multirow[t]{2}{*}{ Personal and Social Integration } & Within Group & 290 & 1.098 & .364 \\
\hline & Total & 299 & & \\
\hline \multirow{3}{*}{ Leadership } & Between Groups & 9 & & \\
\hline & Within Group & 290 & 1.262 & .257 \\
\hline & Total & 299 & & \\
\hline \multirow{3}{*}{ Sense of Belonging } & Between Groups & 9 & & \\
\hline & Within Group & 290 & 1.648 & .101 \\
\hline & Total & 299 & & \\
\hline \multirow{3}{*}{ Confidence } & Between Groups & 9 & & \\
\hline & Within Group & 290 & .390 & .940 \\
\hline & Total & 299 & & \\
\hline
\end{tabular}

${ }^{*} \mathrm{p}<0.05,{ }^{* *} \mathrm{p}<0.01$

Table 6 indicates that no statistically significant differences were found among mean sub-dimension scores in terms of age $(\mathrm{p}>$.05).

ANOVA test findings related to mean sub-dimension scores in terms of monthly expenses are given in Table 7.

Table 7. ANOVA test findings related to mean sub-dimension scores in terms of monthly expenses

\begin{tabular}{|c|c|c|c|c|}
\hline & & df & $\mathbf{F}$ & $\mathbf{P}$ \\
\hline \multirow{3}{*}{ Personal and Social Integration } & Between Groups & 4 & & \\
\hline & Within Group & 295 & 2.954 & $.020^{*}$ \\
\hline & Total & 299 & & \\
\hline \multirow{3}{*}{ Leadership } & Between Groups & 4 & & \\
\hline & Within Group & 295 & 1.943 & .103 \\
\hline & Total & 299 & & \\
\hline \multirow{3}{*}{ Sense of Belonging } & Between Groups & 4 & & \\
\hline & Within Group & 295 & 1.690 & .152 \\
\hline & Total & 299 & & \\
\hline \multirow{3}{*}{ Confidence } & Between Groups & 4 & 1.333 & .258 \\
\hline & Within Group & 295 & & \\
\hline & Total & 299 & & \\
\hline
\end{tabular}

${ }^{* \mathrm{p}}<0.05,{ }^{* *} \mathrm{p}<0.01$

Table 7 indicates statistically significant differences in the sub-dimension of personal and social integration in terms of monthly expenses $(\mathrm{F}=2.954 ; \mathrm{p}=.020)$.

Findings related to multiple comparison test on the significant difference among mean sub-dimension scores in terms of monthly expenses are given in Table 8. 
Table 8. Findings related to multiple comparison test on the significant difference among mean sub-dimension scores in terms of monthly expenses

\begin{tabular}{lcccc}
\hline Monthly Expenses & & Mean Difference & Standard Error & p \\
\hline $\begin{array}{l}\text { Personal and Social } \\
\text { Integration }\end{array}$ & 500 TL and less & 1251 TL and more & & .171 \\
\hline
\end{tabular}

According to Table 8, a statistically significant difference was observed between students who spend 500 TL and those spending $1251 \mathrm{TL}$ and more in the sub-dimension of personal and social integration. This difference is in favour of those spending $500 \mathrm{TL}$ and less. ANOVA test findings related to mean sub-dimension scores in terms of residence type are given in Table 9.

Table 9. ANOVA test findings related to mean sub-dimension scores in terms of residence type

\begin{tabular}{|c|c|c|c|c|}
\hline & & df & $\mathbf{F}$ & $\mathbf{P}$ \\
\hline \multirow[t]{3}{*}{ Personal and Social Integration } & Between Groups & 3 & & \\
\hline & Within Group & 296 & 1.339 & .262 \\
\hline & Total & 299 & & \\
\hline \multirow[t]{3}{*}{ Leadership } & Between Groups & 3 & & \\
\hline & Within Group & 296 & .453 & .715 \\
\hline & Total & 299 & & \\
\hline \multirow[t]{3}{*}{ Sense of Belonging } & Between Groups & 3 & & \\
\hline & Within Group & 296 & 1.862 & .136 \\
\hline & Total & 299 & & \\
\hline \multirow[t]{3}{*}{ Confidence } & Between Groups & 3 & & \\
\hline & Within Group & 296 & .950 & .417 \\
\hline & Total & 299 & & \\
\hline
\end{tabular}

${ }^{* \mathrm{p}}<0.05,{ }^{* *} \mathrm{p}<0.01$

Table 9 indicates that no statistically significant differences were found among mean sub-dimension scores in terms of residence type $(\mathrm{p}>.05)$.

ANOVA test findings related to mean sub-dimension scores in terms of academic department are given in Table 10.

Table 10. ANOVA test findings related to mean sub-dimension scores in terms of academic department

\begin{tabular}{|c|c|c|c|c|}
\hline & & df & $\mathbf{F}$ & $\mathbf{P}$ \\
\hline \multirow[t]{3}{*}{ Personal and Social Integration } & Between Groups & 2 & & \\
\hline & Within Group & 297 & 2.631 & .074 \\
\hline & Total & 299 & & \\
\hline \multirow[t]{3}{*}{ Leadership } & Between Groups & 2 & & \\
\hline & Within Group & 297 & 3.254 & $.040^{*}$ \\
\hline & Total & 299 & & \\
\hline \multirow[t]{3}{*}{ Sense of Belonging } & Between Groups & 2 & & \\
\hline & Within Group & 297 & 4.385 & $.013^{*}$ \\
\hline & Total & 299 & & \\
\hline \multirow[t]{3}{*}{ Confidence } & Between Groups & 2 & & \\
\hline & Within Group & 297 & 2.914 & .056 \\
\hline & Total & 299 & & \\
\hline
\end{tabular}

$$
{ }^{*} \mathrm{p}<0.05,{ }^{* *} \mathrm{p}<0.01
$$

Table 10 indicates statistically significant differences in the sub-dimensions of leadership $(F=3.254 ; p=.040)$ and sense of belonging ( $\mathrm{F}=4.385 ; \mathrm{p}=.013)$ in terms of academic department.

Findings related to multiple comparison test on the significant difference among mean sub-dimension scores in terms of academic department are given in Table 11. 
Table 11. Findings related to multiple comparison test on the significant difference among mean sub-dimension scores in terms of academic department

\begin{tabular}{llllll}
\hline Academic Department & & $\begin{array}{l}\text { Mean } \\
\text { Differences }\end{array}$ & $\begin{array}{l}\text { Standard } \\
\text { Error }\end{array}$ & p \\
\hline Leadership & Physical Education and Sports & $\begin{array}{l}\text { Sports } \\
\text { Management }\end{array}$ & .350 & .138 & .032 \\
\hline $\begin{array}{l}\text { Teaching } \\
\text { Bense of }\end{array}$ & $\begin{array}{l}\text { Physical Education and Sports } \\
\text { Teaching }\end{array}$ & $\begin{array}{l}\text { Coaching } \\
\text { Education }\end{array}$ & .332 & .112 & .009 \\
\hline
\end{tabular}

According to Table 11, a statistically significant difference was found between students studying physical education and sports teaching and those studying sports management in the sub-dimension of leadership. This difference is in favour of those studying physical education and sports teaching. In addition, a statistically significant difference was found between students studying physical education and sports teaching and those studying sports coaching education in the sub-dimension of sense of belonging. This difference, too, is in favour of those studying physical education and sports teaching. ANOVA test findings related to mean sub-dimension scores in terms of sport branch are given in Table 12.

Table 12. ANOVA test findings related to mean sub-dimension scores in terms of sport branch

\begin{tabular}{|c|c|c|c|c|}
\hline & & df & $\mathbf{F}$ & $\mathbf{P}$ \\
\hline \multirow{3}{*}{ Personal and Social Integration } & Between Groups & 2 & \multirow{3}{*}{3.005} & \multirow{3}{*}{.051} \\
\hline & Within Group & 297 & & \\
\hline & Total & 299 & & \\
\hline \multirow{3}{*}{ Leadership } & Between Groups & 2 & \multirow{3}{*}{8.325} & \multirow{3}{*}{$.000^{* *}$} \\
\hline & Within Group & 297 & & \\
\hline & Total & 299 & & \\
\hline \multirow{3}{*}{ Sense of Belonging } & Between Groups & 2 & \multirow{3}{*}{.371} & \multirow{3}{*}{.690} \\
\hline & Within Group & 297 & & \\
\hline & Total & 299 & & \\
\hline \multirow{3}{*}{ Confidence } & Between Groups & 2 & \multirow{3}{*}{9.503} & \multirow{3}{*}{$.000^{* *}$} \\
\hline & Within Group & 297 & & \\
\hline & Total & 299 & & \\
\hline
\end{tabular}

${ }^{* \mathrm{p}}<0.05,{ }^{* *} \mathrm{p}<0.01$

Table 12 indicates statistically significant differences in the sub-dimensions of leadership $(\mathrm{F}=8.325 ; \mathrm{p}<.01)$ and confidence $(\mathrm{F}=9.503 ; \mathrm{p}<.01)$ in terms of sport branch.

Findings related to multiple comparison test on the significant difference among mean sub-dimension scores in terms of sport branch are given in Table 13.

Table 13. Findings related to multiple comparison test on the significant difference among mean sub-dimension scores in terms of sport branch

\begin{tabular}{llllll}
\hline \multicolumn{2}{l}{ Sport Branch } & & $\begin{array}{l}\text { Mean } \\
\text { Differences }\end{array}$ & $\begin{array}{l}\text { Standard } \\
\text { Error }\end{array}$ & p \\
\hline \multirow{2}{*}{ Leadership } & \multirow{2}{*}{ Team Sports } & Individual Sports & .335 & .100 & .003 \\
& & No Sport Branch & .538 & .166 & .004 \\
\hline \multirow{2}{*}{ Confidence } & \multirow{2}{*}{ Individual Sports } & Team Sports & .500 & .120 & .000 \\
& & No Sport Branch & .494 & .199 & .036 \\
\hline
\end{tabular}

According to Table 13, a statistically significant difference was found between students being involved in team sports and those being involved in individual sports and those being involved in no sport branch in the sub-dimension of leadership. This difference is in favour of those being involved in team sports. In addition, statistically significant differences were found between students being involved in individual sports and those being involved in team sports and those being involved in no sport branch in the sub-dimension of confidence. This difference is in favour of those being involved in individual sports.

\section{Discussion and Conclusion}

This study aims to determine socialization situations via sport-based physical activity among students at a school of physical education and sports in terms of their demographic features. In this respect, the sample of the study comprises of 300 students studying at School of Physical Education and Sports at University of Yozgat Bozok. 
The findings of the present study suggest that the most important sub-dimension of the socialization via sport-based physical activities scale is personal and social integration. Filiz (2010) conducted a study on the analysis and comparison of sport and socialization situations among students at Eskisehir Osmangazi University and Anadolu University. 124 students at Eskisehir Osmangazi University and 124 students at Anadolu University participated in the study, thus making a total of 248 participants. It was reported in this study that sport made social integration easier in spite of personal differences. Similarly, Yilmaz (2006) demonstrated that participation in outdoor sports result in a social integration in spite of personal differences. Ozcelik (2007) carried out a study on the impact of physical education and sports classes on primary school students' socialization, and applied a questionnaire to 160 students in 7 different primary schools in Tuzla district of Istanbul. 22 questions regarding the impact of physical education classes on socialization were asked in this questionnaire, and the obtained data indicated that education sport activities greatly influenced an individual's socialization. Another study by Kaya (2003) found out that female and male students aged between 13 and 18 participated in leisure activities. It was reported in this study that joining leisure time activities helped students communicate and familiarize with other people, make new friends, increase their confidence and responsibility, and relaxed them physically. It was also pointed out that male students preferred taking part in sports activities, whereas female students usually took part in passive activities. It was observed that students participating in such activities had a higher level of socialization and personality compared to those who did not. Therefore, the findings of this study overlap the present study.

The findings of the present study indicate a statistically significant difference between sport-based physical activity and mean sub-dimensions scores in the sub-dimension of confidence when it comes to gender. It was observed in this subdimension that female students had a higher level of socialization via sport-based physical activity compared to male students. In a study titled "The Analysis of Participation in Sports among University Students", Filiz (2010), too, reported that female students had a higher level of socialization compared to male students. In a study titled “University Students' Socialization Process and Recreation Activities", Yagmur \& Icigen (2016) found a significant correlation between gender and socialization. In a study on high school students, Yildiran et al. (1996) found out some differences between male and female students in terms of participation in sports. The findings of this study demonstrated that female students participated in sports activities for social, ethical, aesthetic and rhythmic reasons, while male students primarily aimed at body building. In their respective studies, Theberge (2000) and Abraham (1998), similarly, indicated that female athletes had a higher level of socialization via sports activities compared to male athletes. An increasing level of physical activity also increases an individual's confidence, thus greatly contributing to their daily performance and productivity. In addition, their material and spiritual satisfaction will significantly rise. It is also considered that regular physical activities will positively influence an individual's socialization level and life quality as well. People who are involved in regular physical activities during their adolescence are more likely to avoid harmful habits and addictions, follow a healthy diet, lead a disciplined life and become a more confident and responsible individual in the future. Various studies support this finding. On the other hand, Treanor et al. (1998) and Ozdinc (2005) reported that males had a higher level of socialization via sport activities compared to females, which contradicts the findings of the present study.

The findings of the present study indicate statistically significant differences between sport-based physical activity and mean sub-dimension scores in the sub-dimension of personal and social integration when it comes to monthly expenses. It was observed in this sub-dimension that students who spend $500 \mathrm{TL}$ and less had a higher level of socialization via sport-based physical activities compared to those spending $1251 \mathrm{TL}$ and more. It can be stated that socio-economic status influence people's life style, and economic welfare remarkably shapes an individual's living conditions, which, unsurprisingly, increases participation in sport-based physical activities and socialization levels. Farrell and Shields (2002), Rimal (2002) and Fogelman et al. (2004) also support this finding in their respective studies. Contrary to these studies, however, it was found out in the present study that students with a lower level of income had a higher level of socialization. Therefore, it is likely that students studying at developing universities manage to contribute to their personal and social developments by familiarizing with other students and making new friends through various sports and leisure activities although these universities do not offer extensive campus facilities.

The findings of the present study indicate statistically significant differences between sport-based physical activities and mean sub-dimension scores in the sub-dimensions of leadership and sense of belonging when it comes to academic department. It was found out that students studying physical education and sports teaching had a higher level of socialization via sport-based physical activities compared to those studying sports management and coaching education in the sub-dimensions of leadership and sense of belonging, respectively. Various studies have so far focused on the impact of games, competitions, physical activities and sports, and demonstrated that participation in these activities enabled people to learn internal and external relations in a sport as well as supporting their personal development from different angles (Yetim, 2006; 171, Laker, 2000; 82). Kelinske et al. (2001) listed university students' perception of benefits from participation in physical activities and sports as socialization, competitiveness, health, wellness, leadership and sense of belonging. Yaman et al. (2003), Yakupoglu (1996), Weinberg et al. (2010), and Honeybourne et al. (2004) concluded in their respective studies that sports contribute to personal development positively. In this respect, it can be argued that leadership qualities and sense of belonging among students studying 
physical education and sports teaching are higher compared to those studying sports management and coaching education.

The findings of the present study indicate statistically significant differences between sport-based physical activities and mean sub-dimension scores in the sub-dimensions of leadership and sense of confidence when it comes to sport branches. It was observed in the sub-dimension of leadership that students being involved in team sports had a higher level of socialization via sport-based physical activities compared to those being involved in individual sports and no sport branch. On the other hand, it was also observed in the sub-dimension of confidence that students being involved in individual sports had a higher level of socialization via sport-based physical activities compared to those being involved in team sports and no sport branch. A study by Nia and Besharat (2010) focused on personal traits among students being involved in individual and team sports. It was reported in this study that students being involved in individual sports had higher scores for responsibility and autonomy compared to those being involved in team sports, while students being involved in team sports had higher scores for leadership, tendency for collaboration and sincerity. In a study on the role of sports activities on socialization process for university students, Sahan (2007) conducted a questionnaire on 4613 students studying at Gazi University and Selcuk University. The findings of this study demonstrated that sports activities occupy an important position in university students' socialization process along with family, educational institutions, circle of friends, cultural structure and other socialization factors, which overlap the findings of the present study.

The following recommendations can be made in parallel with the findings of the present study:

Numerous studies should be conducted bearing in mind the fact that sports activities are as important as schools, family, circle of friends and socio-cultural structure in a city for university students' socialization process.

- Different instruments (educational games and exercise games) must be used in the socialization process by taking the impact of physical activity and sports on socialization.

- Symposiums and seminars should be organized in order to inform students about spending their leisure time more productively and effectively and thus to increase their participation in physical activities and social organizations.

- Physical conditions should be improved and new facilities should be introduced in developing universities through a meticulous planning process. In addition, necessary equipment and hardware should be offered for university students to enable them to spend more time in physical activities.

- New sport organizations should be held in different sport branches in order to attract students' attention and increase their participation in these games.

- $\quad$ Sport organizations and tournaments in university campuses should be extended over an academic year rather than being organized within a fairly limited period of time.

- Different social, cultural and sports activities must be organized in university campuses in order to encourage students studying not only at school of physical education and sports but also at other departments to familiarize with each other and make new friends.

\section{References}

Abraham, A. (1998). Geschlecht als strukturdimension sozialer ungleichheit im sport, in: K. Cachayand I. HartmannTews (Ed.) Sport und Soziale Ungeichkeit.

Acik Ogretim Fakultesi [Open Education System]. (2003). Introduction to Behavioral Sciences. Eskisehir: Anadolu University Publishing.

Cosgun, M. (2012). Identity development in youth and the impact of TV series on socialization process (A case study on Kocaeli district of Sakarya), Journal of Academic Perspective, 28, 1-21.

Cokluk, O., Sekercioglu, C., \& Buyukozturk, S. (2010). Multi variable statistics in social sciences: SPSS and lisrel applications. Ankara: Pegem Publishing.

Caha, O. (1999). Breathing through sports. Journal of Political Thinking, 1(2), 115-125.

Donmezer, S. (1984). Sociology. Ankara: Savas Publishing.

Erkal, M., Guven, O., \& Ayan, D. (1998). Sport from a Sociological Perspective. Istanbul: Der Publishing.

Erkal, M. (1986). Sport from a Sociological Perspective. Ankara: MEB Publishing.

Farrell, L., \& Shields, M.A. (2002). Investigatingtheeconomicanddemographicdeterminants of sportingparticipation in England. Journal of Royal Statistical Society, 165, 335-348. 
Filiz, Z. (2010). The impact of participation in sports in university students' socialization. University of Nigde Journal of Physical Education and Sport Sciences, 4(3), 192-203.

Fogelman, Y., Bloch, B., \& Kahan, E. (2004). Assesment of participation in physical activities and relationship to socio economic and health factors. Patient Education and Counselling, 53, 95-99

Guney, S. (2000). Behavioral Sciences. Ankara: Nobel Publishing.

Guven, O. (1998). Class Notes on Sports Psychology, Gazi University School of Physical Education and Sports, Ankara, 2223.

Honeybourne, J., Hill, M., \& Moors, H. (2004). Advanced PE andSport (3rd ed.). Cheltenham, UK: Nelson Thornes Ltd.

Ikizler, C. (2000). Social sciences in sports. Istanbul: Alfa Publishing..

Kagitcibasi, C. (1999). New human and people. Istanbul: Evrim Publishing.

Karakus, S., \& Kucuk, V. (1999). Physical education and sport activities in secondary schools within the framework of education, Dumlupinar University Journal of Social Sciences, 1(1), 279-293.

Kaya, S. (2003). The impact of leisure time activities and tendencies among adolescents living in orphanages (Unpublished (doctorate dissertation). Gazi University, Ankara, Turkey.

Kaya, M. (2011). Confirmatory factor analysis and its application to schutten emotional intelligence scale (Unpublished master's thesis). Eskisehir Osmangazi University, Eskisehir, Turkey.

Kelinske, B., Mayer, B.W., Chen, K.L. (2001). Perceived benefits from participation in sports: a gender study. Women in Management Review, 16(2), 75-84.

Kenyon, G., Mc Pherson B. (1974). Approach to the study of sport socialization, International Review of Sport Sociology, 9(1), 127-129.

Keten, M. (1974). Sports in Turkey. Ankara: Ayyildiz Publishing.

Laker, A. (2000). Beyond the boundaires of physical education. Newyork: 1.st Publised. Routledge Falmer.

Mengutay, S. (2006). Movement Development in children and sports. Istanbul: Morpa Publishing.

Meydan, C. H., \& Sesen, H., (2011). Structural equation modelling, Amos Applications. Ankara: Detay Publishing.

Ministry of Education (2012). Questions about Public Relations and Organization Services. Ankara.

Nia, M. E., \& Besharat, M.A. (2010). Comparison of Athletes Personality Characteristics in Individual and Team Sports, Procedia Social and Behavioral Sciences, 5, 808-812.

Orlick, T. D. (1974). Sport Participation, A Process of Shaping Behavior, Human Factors, cited by: Sahan, H., (2007). The role of sports activities in university students' socialization, Unpublished PhD Thesis, Selcuk University, Konya.

Ozcelik, E. (2007). The role of physical education on students' socialization (Unpublished master's thesis). Beykent University, Ankara, Turkey.

Ozdamar, K. (1999). Biostatistics with SPSS. Eskisehir: Kaan Bookstore.

Ozdinc, O. (2005). Opinions of students of Cukurova University on the relation of sports and sport participation to socialization, Spormeter Journal of Physical Education and Sports, 3(2) 77-84.

Pooley, J. (1981). Dropouts from Sport, A Case Study of Boys Age-Group Soccer, Paper Presented at the Annual Convention of the American Alliance for Health, Physical Education, Recreation and Dance, Boston, MA, cited by: Sahan, H., (2007). The role of sports activities in university students' socialization (Unpublished doctorate dissertation). Selcuk University, Konya, Turkey.

Rimal, A. (2002). Association of nutrition concers and socio economic status with exercise habits. International Journal of Concumer Studies, 26(4), 322-327.

Sayin, O. (1999). One-Way Decisiveness of Television on Children's Socialization in Family Environment, Symposium on Child in Communicative Environments. Eskisehir: Anadolu University Faculty of Communication Publications.

Schermelleh, E.K., Moosbrugger, H., \& Muler, H. (2003). Evaluating the fit of structural equation models: tests of significance and descriptive goodness-of-fit measures, Methods of PsychologicalResearch Online, 8(2), 23-74.

Sahan, H. (2007). The role of sports activities in university students' socialization (Unpublished doctorate dissertation). Selcuk University, Konya, Turkey.

Theberge, N. (2000). Gender and sport, In: J. Coakleyand E. Dunning (Ed.), Handbook of Sport Studies. 
Tolan, B. (1993). Sociology. Ankara: Adim Publishing.

Tolan, B. (1987). Introduction to Sociology, Ankara: Kalite Printery.

Treanor, L., Graber, K., Housner, L., \& Wiegand, R. (1998). Middle school students perception of coeducational and same-sex physical education classes. Journal of Teaching in PhysicalEducation, 18, 43-56.

Yagmur, Y., \& Icigen, T. E. (2016). A study on the analysis of university students' socialization process and recreation activities. Anatolia Journal of Tourism Research, 27(2), 227-242.

Yakupoglu, S. (1996). The analysis of personal traits in individuals sports requiring open and closed skills (Unpublished master's thesis). Mersin University, Mersin, Turkey.

Yaman, M., Yaman, T., \& Turkmen, M. (2003). The impact of sport on university student candidates' assertive and practical personality traits, University of Sakarya Journal of Educational Sciences, 5, 16-132.

Yetim, A. (2006). Sociology and sport. Istanbul: Morpa Publishing.

Yetim, A. (2000). Sociology and sport. Ankara: Topkar Printery.

Yildiran, I., \& Yetim A. (1996). A study on the principal purposes of physical education and sports classes in secondary school. Gazi University Journal of Physical Education and Sports Sciences, 1(3), 36-43.

Yildiran, I., Yetim, A., \& Senel, O. (1996). Male and female students' expectations from physical education classes. Journal of Physical Education and Sports Sciences, 1(1), 52-57.

Yildirim, M. (2015). The Participation of University Students in Physical Activities Based on Sport and The Effect of The Students' quality of Life on Academic Achievement and Socialisation (Sample of Eskisehir Osmangazi University) (Unpublished doctorate dissertation). Anadolu University, Eskisehir, Turkey.

Yilmaz, B. (2006). The impact of participation in outdoor sports on social integration (Unpublished doctorate dissertation). Gazi University, Ankara, Turkey.

Weinberg, R.S., \& Gould, D. (2010). Foundations of Sport and Exercise Psychology. Chanpaign, IL: Human Kinetics. 